\title{
PERBEDAAN HASIL BELAJAR MATEMATIKA SISWA MENGGUNAKAN MODEL PEMBELAJARAN SNOWBALL THROWING DAN MODEL TALKING STICK
}

\author{
Mohamad Syafi'i ${ }^{1}$, Kiki Fatmalawati ${ }^{2}$ \\ ${ }^{1}$ Program Studi Pendidikan Matematika STKIP Kusumanegara, Jakarta \\ syafii.enha@gmail.com
}

\begin{abstract}
Abstrak: Penelitian ini dilakukan untuk mengetahui ada tidaknya perbedaan hasil belajar matematika dengan menggunakan model pembelajaran Snowball Throwing dan model pembelajaran Talking Stick. Model pembelajaran Snowball Throwing merupakan model pembelajaran yang melibatkan siswa aktif dalam proses pembelajaran dengan kegiatan memberikan pertanyaan kepada siswa lain dengan cara melempar bola kertas. Model pembelajaran Talking Stick merupakan model pembelajaran dengan media tongkat, siapa yang memegang tongkat wajib menjawab pertanyaan yang diberikan oleh guru. Penelitian ini dilakukan di SMA Asyariah Gintung, Tangerang pada bulan Maret sampai April 2017. Berdasarkan hasil penelitian, rata-rata hasil belajar matematika menggunakan model Snowball Throwing adalah 80,1 sedangkan rata-rata hasil belajar matematika menggunakan model Talking Stick adalah 60,83. Dalam penelitian komparasional ini, pengujian hipotesis statistik menggunakan uji - t. Hasil analisis data uji beda dua rata - rata hasil belajar matematika menggunakan uji $-\mathrm{t}$ diperoleh $t_{\text {hitung }}=6.712$ dan $t_{\text {tabel }}=2.002$ dengan $d k=58$ dan $\alpha=0.05$. Berdasarkan hasil tersebut dapat disimpulkan bahwa $t_{\text {hitung }}>t_{\text {tabel }}$ yang artinya terdapat perbedaan hasil belajar matematika siswa dengan menggunakan model pembelajaran Snowball Throwing dan model pembelajaran Talking Stick.
\end{abstract}

Kata Kunci: Hasil Belajar Matematika, Model Snowball Throwing, Model Talking Stick.

\section{Pendahuluan}

Pembelajaran matematika merupakan bagian penting dari proses pendidikan di sekolah yang diharapkan dapat mengembangkan kemampuan berpikir, bersikap, danbertindak. Tidak bisa dipungkiri mata pelajaran matematika masih dianggap sebagai pelajaran yang menakutkan. Seorang guru matematika mempunyai tugas besar yang pertama bagaimana peserta didik harus nyaman ketika di dalam kelas. Oleh karena itu setidaknya setiap materi pembelajaran bisa dilaksanakan dengan berbagai variasi metode pembelajaran. Hal ini bertujuan untuk menghilangkan sedikit rasa bosan dan jenuh terhadap pembelajaran matematika. Proses belajar mengajar merupakan aktifitas paling utama. Melalui proses inilah tujuan pendidikan akan dicapai dalam bentuk perubahan perilaku siswa. Proses pembelajaran yang kurang baik terjadi jika anak kurang didorong untuk mengembangkan kemampuan berpikir.

\section{SMA Asyariah Gintung} Tangerang merupakan salah satu institusi pendidikan yang mengajarkan matematika sebagai salah satu bahan ajar yang sangat penting untuk diberikan kepada siswa. Pembelajaran matematika di SMA Asyariah Gintung Tangerang ini banyak menemukan permasalahan yang muncul terkait dengan metode pembelajaran matematika yang dilakukan. Pembelajaran matematika di kelas $\mathrm{X}$ SMA Asyariah Gintung Tangerang masih didominasi oleh guru 
sehingga siswa cenderung pasif dan hanya beberapa siswa yang aktif bertanya. Karena kondisi seperti itu beberapa siswa kurang bersemangat dalam belajar matematika dan merasa kemampuan mereka dalam memahami konsep matematika masih kurang sehingga berasumsi bahwa matematika itu sulit. KKM yang ditetapkan sekolah adalah 70 , tentunya harus diimbangi dengan model pembelajaran yang sesuai sehingga KKM yang ditetapkan bisa tercapai. Berdasarkan hal tersebut maka peneliti berasumsi perlu adanya inovasi proses pembelajaran yang melibatkan siswa, sehingga siswa selalu aktif dalam proses pembelajaran.

Salah satu model pembelajaran yang dapat dilakukan adalah model Snowball Throwing. Langkah - langkah pada model pembelajaran Snowball Throwing adalah siswa dibagi menjadi beberapa kelompok yang masing masing kelompok diwakili seorang ketua kelompok untuk mendapat tugas dari guru. Masing - masing siswa membuat pertanyaan di selembar kertas yang dibentuk seperti bola (kertas pertanyaan) lalu dilempar ke siswa lain. Siswa yang mendapat lemparan kertas harus menjawab pertanyaan dalam kertas yang diperoleh. Model pembelajaran ini melatih siswa untuk saling memberikan pengetahuan sehingga diharapkan mereka bisa memahami materi dengan diberikan diskusi, selain itu diharapkan siswa selalu komunikatif sehingga proses pembelajaran menjadi menyenangkan dan tidak membosankan.

Model pembelajaran lain yang digunakan dalam pembelajaran ini adalah model pembelajaran Talking Stick. Model ini sudah digunakan sebagai model pembelajaran ruang kelas, langkah langkahnya adalah guru membagi kelas menjadi kelompok - kelompok dengan anggota 5 atau 6 siswa. Guru menyiapkan sebuah tongkat setelah itu guru menyampaikan materi pokok yang akan dipelajari dan memberikan kesempatan para kelompok untuk membaca dan mempelajari materi pelajaran. Setelah siswa selesai membaca materi pelajaran dan mempelajari isinya, guru mempersilahkan siswa untuk menutup isi bacaan. Dan guru mengambil tongkat dan memberikan kepada salah satu siswa, setelah itu guru memberikan pertanyaan dan siswa yang memegang tongkat harus menjawabnya.

Berdasarkan latar belakang tersebut, maka perlu penerapan model pembelajaran Snowball Throwing dan model pembelajaran Talking Stick pada mata pelajaran matematika untuk meningkatkan peran aktif siswa sehingga hasil belajar siswa kelas $\mathrm{X}$ di SMA Asyariah Gintung Tangerang juga diharapkan meningkat. Adapun materi yang digunakan pada penelitian ini adalah materi logika matematika. Pada penelitian ini juga dibatasi hanya untuk mengetahui ada tidaknya perbedaan hasil belajar matematika dengan menggunakan model pembelajaran Snowball Throwing dan model pembelajaran Talking Stick pada materi logika matematika.

\section{Tinjauan Pustaka \\ Hasil belajar}

Belajar diartikan sebagai proses perubahan tingkah laku pada diri individu, berkat adanya interaksi antara individu dan individu dengan lingkungan.

Terdapat kata perubahan dalam pengertian ini yang berarti bahwa seseorang setelah mengalami proses belajar akan mengalami perubahan tingkah laku, baik aspek pengetahuannya, keterampilannya, maupun aspek sikapnya (Hidayat, 2012:83)

Hasil belajar atau achievement dapat berupa perubahan tingkah laku, kecakapan dan status siswa dalam 
menelaah materi belajar pada jangka waktu tertentu. Hasil belajar juga merupakan realisasi dari kecakapan kecakapan potensial atau kapasitas yang dimiliki seseorang, baik perilaku dalam bentuk penguasaan, pengetahuan, keterampilan berpikir maupun kemampuan keterampilan motorik (Syaodih, 2004: 102).

Evaluasi atau penilaian adalah alat untuk mengukur dan menilai sampai di mana tujuan pengajaran telah tercapai, baik dari siswa maupun guru, ruang lingkup kegiatan hasil belajar siswa dan aspek pengetahuan, keterampilan serta sikap setelah mengikuti program pengajaran (Nurkancana, 2013: 2).

\section{Model Pembelajaran Snowball Throwing}

Model pembelajaran Snowball Throwing merupakan pembelajaran yang diadopsi pertama kali dari game fisik dimana segumpal salju dilempar dengan maksud memukul orang lain. Snowball Throwing diterapkan dengan melempar segumpalan kertas untuk menunjukkan siswa yang harus menjawab soal dari guru. Model ini digunakan untuk memberikan konsep pemahaman materi yang sulit kepada siswa serta dapat juga digunakan untuk mengetahui sejauh mana pengetahuan dan kemampuan siswa dalam materi tersebut (Huda, 2013: 226).

Pada pembelajaran Snowball Throwing siswa dibagi menjadi beberapa kelompok masing - masing kelompok diwakili seorang ketua kelompok untuk mendapat tugas dari guru. Kemudian, masing - masing siswa membuat pertanyaan di selembar kertas yang dibentuk seperti bola (kertas pertanyaan) kemudian dilempar ke siswa lain. Siswa yang mendapat lemparan kertas harus menjawab pertanyaan dalam kertas yang diperoleh.
Langkah - langkah metode pembelajaran Snowball Throwing adalah sebagai berikut :

a. Guru menyampaikan materi yang akan disajikan.

b. Guru membentuk kelompok kelompok dan memanggil masing masing ketua kelompok untuk memberikan penjelasan tentang materi.

c. Masing - masing ketua kelompok kembali ke kelompoknya masing masing kemudian menjelaskan materi yang disampaikan oleh guru kepada teman sekelompoknya.

d. Masing - masing siswa diberikan satu lembar kertas kerja untuk menuliskan satu pertanyaan apa saja yang menyangkut materi yang sudah dijelaskan oleh ketua kelompok.

e. Siswa membentuk kertas tersebut seperti bola dan dilempar dari satu siswa ke siswa lain selama +15 menit.

f. Setelah siswa mendapat satu bola, ia diberikan kesempatan untuk menjawab pertanyaan yang tertulis dalam kertas tersebut secara bergantian.

g. Guru mengevaluasi dan menutup pembelajaran (Huda, 2013: 227).

\section{Model Pembelajaran Talking Stick}

Pada mulanya model Talking Stick adalah model yang digunakan oleh penduduk asli Amerika untuk mengajak semua orang berbicara atau menyampaikan pendapat dalam suatu forum (pertemuan antar suku). Kini model itu sudah digunakan sebagai model pembelajaran ruang kelas. Sebagaimana namanya, Talking Stick merupakan model pembelajaran kelompok dengan bantuan tongkat. Setelah itu guru membuat permainan dengan bantuan tongkat, siapa yang memegang tongkat wajib menjawab pertanyaan dari guru setelah peserta didik mempelajari materi pokoknya. Kegiatan ini diulang terus menerus sampai semua 


\section{Pi: Mathematics

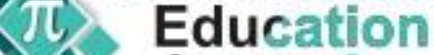 \\ Journal}

siswa mendapat giliran untuk menjawab pertanyaan dari guru (Huda, 2013: 224).

Langkah - langkah metode Talking Stick adalah sebagai berikut:

a. Guru menyiapkan sebuah tongkat yang panjang $\pm 20 \mathrm{~cm}$.

b. Guru menyampaikan materi pokok yang akan dipelajari, kemudian memberikan kesempatan para kelompok untuk membaca dan mempelajari materi pelajaran.

c. Siswa berdiskusi membahas masalah yang terdapat di dalam wacana.

d. Setelah siswa selesai membaca materi pelajaran dan mempelajari isinya, guru mempersilahkan siswa untuk menutup isi bacaan.

e. Guru mengambil tongkat dan memberikan kepada salah satu siswa, setelah itu guru memberi pertanyaan dan siswa yang memegang tongkat tersebut harus menjawabnya. Demikian seterusnya sampai sebagian besar siswa mendapat bagian untuk menjawab setiap pertanyaan dari guru.

f. Guru memberi kesimpulan.

g. Guru melakukan evaluasi/penilaian.

h. Guru menutup pembelajaran (Huda, 2013:225).

\section{Metode Penelitian}

\section{Jenis Penelitian}

Jenis penelitian ini adalah penelitianeksperimen. Desain penelitian ini adalah Quasi Eksperimental design. Desain eksperimen ini merupakan pengembangan dari true experimental design, yang sulit dilaksanakan. Desain ini mempunyai kelompok kontrol, tetapi tidak dapat berfungsi sepenuhnya untuk mengontrol variabel-variabel luar yang mempengaruhi pelaksanaan eksperimen. (Sugiyono, 2012: 114).

\section{Waktu dan Tempat Penelitian}

Penelitian ini dilaksanakan di SMA Asyariah Gintung Tangerang dan penelitian ini dilakukan pada bulan Maret sampai dengan April 2017.

\section{Populasi dan Sampel}

Populasi target pada penelitian ini adalah seluruh siswa semester genap SMA Asyariah Gintung Tangerang tahun pelajaran 2016/2017. Sedangkan populasi terjangkau pada penelitian ini adalah seluruh siswa kelas X SMA Asyariah Gintung Tangerang tahun pelajaran 2016/2017. Penentuan sampel pada penelitian ini dengan Cluster Random Samplingdan diperoleh kelas X-A dijadikan sebagai kelompok eksperimen dengan model pembelajaran Snowball Throwing dan kelas X-B dijadikan sebagai kelas kontrol dengan model pembelajaran Talking Stick.

\section{Desain Penelitian}

Adapun rancangan atau desain penelitian yang digunakan pada penelitian ini adalah:

Tabel 1. Desain Penelitian

\begin{tabular}{cccc}
\hline Kelompok & Kelas & Perlakuan & $\begin{array}{r}\text { Post } \\
\text { Test }\end{array}$ \\
\hline \multirow{2}{*}{ Eksperimen } & X-A & $\begin{array}{c}\text { Pembelajaran } \\
\text { Snowball } \\
\text { Throwing }\end{array}$ & $P_{1}$ \\
& & Model & \\
\hline \multirow{2}{*}{ Kontrol } & X-B & $\begin{array}{c}\text { Pembelajaran } \\
\text { Talking Stick }\end{array}$ & $P_{2}$ \\
& & T
\end{tabular}




\section{Teknik Analisis data}

Teknik analisis data yang digunakan dalam penelitian ini yaitu hanya membandingkan rata-rata nilai hasil belajar matematika siswa dengan menggunakan uji - t. Sebelum dilakukan $u j i-t$ dilakukan uji prasyarat terlebih dahulu yaitu uji normalitas dengan menggunakan uji Liliefors dan uji Homogenitas dengan menggunakan uji Fisher.

Adapun Hipotesis statistik yang digunakan dalam penelitian ini adalah :

$H_{0}: \overline{x_{1}}=\overline{x_{2}}$

$H_{1}: \overline{x_{1}} \neq \overline{x_{2}}$

Dan kriteria pengujiannya adalah:

Terima $H_{0}$, jika $t_{\text {hitung }}<t_{\text {tabel }}$

Terima $H_{1}$, jikat $t_{\text {hitung }}>t_{\text {tabel }}$

Keterangan:

$H_{0}$ : tidak terdapat perbedaan rata - rata hasil belajar matematika menggunakan model Snowball Throwing dengan model Talking Stick.

$H_{1}$ : terdapat perbedaan rata - rata hasil belajar matematika menggunakan model Snowball Throwing dengan model Talking Stick.

$\overline{x_{1}}$ : rata - rata hasil belajar matematika dengan model Snowball Throwing.

$\overline{x_{2}}$ : rata - rata hasil belajar matematika dengan model Talking Stick.

\section{Hasil dan Pembahasan \\ Deskripsi Data Hasil Belajar dengan Menggunakan Model Snowball Throwing}

Deskripsi data hasil belajar matematika siswa menggunakan model Snowball Throwing adalah sebagai berikut:
Tabel 2. Deskripsi Data Hasil Belajar dengan Model Snowball Throwing

\begin{tabular}{ccc}
\hline No. & Data Statistika & Nilai \\
\hline 1 & Rata - Rata $\left(\overline{X_{1}}\right)$ & 80,1 \\
2 & Modus & 89,5 \\
3 & Median & 80,5 \\
4 & NilaiTerendah & 63 \\
5 & NilaiTertinggi & 96 \\
6 & Varians $\left(S^{2}\right)$ & 108,45 \\
7 & Simpangan Baku $(S)$ & 10,41 \\
\hline
\end{tabular}

Berdasarkan Tabel.2 rata - rata hasil belajar matematika kelas X-A dengan menggunakan model pembelajaran Snowball Throwing pada materi logika matematika adalah 80,1. Nilai siswa yang mendapatkan nilai di bawah rata rata sebanyak 15 siswa dan nilai siswa yang mendapatkan nilai di atas rata rata sebanyak 15 siswa juga, dengan nilai terendah 63 dan nilai tertinggi 96. Berdasarkan KKM untuk mata pelajaran matematika terdapat 25 siswa yang mencapai ketuntasan atau sebesar $83 \%$. Model pembelajaran ini sangat disukai siswa, selain mereka bisa belajar dalam memahami materi dalam pembelajaran ini juga disisipkan sebuah permainan, sehingga membuat siswa terlihat aktif dalam pembelajaran dan melatih kesiapan siswa dalam merumuskan pertanyaan dan membangkitkan siswa dalam bekerja sama sehingga dapat menyelesaikan pertanyaan yang diberikan kelompok lain.Tentunya pada model pembelajaran ini siswa berpartisipasi secara langsung, baik ketika melibatkan siswa membuat pertanyaan dan menjawab pertanyaan. 
Sehingga dalam model pembelajaran ini melatih meningkatkan berfikir kritis, partisipasi demokratis yang pada gilirannya mampu meningkatkan motivasi belajar siswa secara efektif. Pada model pembelajaran ini masih terdapat kendala, salah satunya adalah terlalu gaduh sehingga kondisi kelas seperti tidak kondusif tetapi hal ini bisa diatasi dengan guru membuat peraturan yang harus dilaksanakan ketika pembelajaran berlangsung dan pada pembelajaran ini membutuhkan alokasi waktu yang cukup lama sehingga untuk mengatasi masalah ini guru memberikan tugas membaca dan mamahami materi yang akan disampaikan selanjutnya dengan dibuktikan siswa membuat rangkuman materi berikutnya dan mencatat hal - hal yang belum dipahami terkait materi yang akan disampaikan.

\section{Deskripsi Data Hasil Belajar dengan Menggunakan Model Talking Stick}

Deskripsi data hasil belajar matematika siswa menggunakan model Talking Stick adalah sebagai berikut:

Tabel 3. Deskripsi Data Hasil Belajar dengan Model Talking Stick

\begin{tabular}{ccc}
\hline No. & Data Statistika & Nilai \\
\hline 1 & Rata - Rata $\left(\overline{x_{2}}\right)$ & 60,83 \\
2 & Modus & 65,68 \\
3 & Median & 60,86 \\
4 & NilaiTerendah & 40 \\
5 & NilaiTertinggi & 85 \\
6 & Varians $\left(S^{2}\right)$ & 138,75 \\
7 & Simpangan Baku $(S)$ & 11,77 \\
\hline
\end{tabular}

Berdasarkan Tabel. 3 rata - rata hasil belajar matematika kelas X-B dengan menggunakan model pembelajaran Talking Stick pada materi logika matematika adalah 60,83 . Nilai siswa yang mendapatkan nilai di bawah rata - rata sebanyak 16 siswa dan nilai siswa yang mendapatkan nilai di atas rata - rata sebanyak 14 siswa, dengan nilai terendah 40 dan nilai tertinggi 85. Berdasarkan KKM untuk mata pelajaran matematika terdapat 21 siswa yang tidak mencapai ketuntasan atau sebesar $70 \%$. Dalam model pembelajaran ini setelah guru memberikan materi, siswa dibagi menjadi kelompok kecil. Tujuannya agar mereka dapat berdiskusi sesuai dengan pengetahuan yang mereka dapat. Setelah itu guru membuat permainan dengan bantuan tongkat, siapa yang memegang tongkat wajib menjawab pertanyaan dari guru setelah peserta didik mempelajari materipokoknya. Model pembelajaran ini lebih menguji kesiapan siswa dalam pembelajaran dan melatih siswa memahami materi dengan cepat. Kelemahan pada pembelajaran ini adalah selain alokasi pembelajaran yang memakan waktu lebih lama, pembelajaran model ini lebih menguntungkan siswa yang berkemampuan tinggi dan siswa yang lebih cepat menghafal. Bagi siswa yang berkemampuan rendah mereka lebih cenderung kurang siap dan sulit menjawab pertanyaan. Pada pembelajaran dengan menggunakan model ini beberapa siswa yang terlihat gugup dan kurang konsentrasi dalam menjawab soal mengakibatkan siswa yang dalam kondisi normal seharusnya bisa menjawab pertanyaan dengan benar, dapat mengalami lupa kerena terlalu gugup. Tetapi hal ini menjadi bahan evaluasi sehingga mempunyai catatan pada materi - materi yang belum dipahami siswa dan selalu menciptakan suasana yang santai sehingga siswa dalam mengikuti pembelajaran tidak terlalu tegang. 


\subsection{Pengujian Prasyarat Analisis Data}

Untuk mengetahui apakah terdapat perbedaan rata - rata hasil belajar matematika yang menggunakan model pembelajaran Snowball Throwingdan model pembelajaran Talking Stickdengan uji-t. Terlebih dahulu dilakukan uji prasyarat analisis diantaranya uji normalitas dan uji homogenitas. Uji normalitas pada penelitian ini menggunakan uji Liliefors dengan taraf signikansi $\alpha=5 \%$, dan uji homogenitas dengan menggunakan uji Fisherdengan taraf signikansi $\alpha=5 \%$.

\section{Hasil Uji Normalitas}

Tabel 4. Uji Normalitas

\begin{tabular}{|c|c|c|c|c|c|}
\hline $\begin{array}{l}\text { Kel } \\
\text { om } \\
\text { pok }\end{array}$ & $\begin{array}{l}\text { Kel } \\
\text { as }\end{array}$ & $\begin{array}{c}\text { Bany } \\
\text { aknya } \\
\text { Sam } \\
\text { pel }\end{array}$ & $L_{\text {hitung }}$ & $L_{\text {tabel }}$ & $\begin{array}{l}\text { Kesimpu } \\
\quad \text { lan }\end{array}$ \\
\hline $\begin{array}{l}\text { Eks } \\
\text { peri } \\
\text { men }\end{array}$ & $\mathrm{X}-\mathrm{A}$ & 30 & 0,1186 & 0,161 & $\begin{array}{c}\text { Data } \\
\text { Berdistri } \\
\text { busi } \\
\text { Normal }\end{array}$ \\
\hline $\begin{array}{c}\text { Kon } \\
\text { trol }\end{array}$ & X-B & 30 & 0,0946 & 0,161 & $\begin{array}{c}\text { Data } \\
\text { Berdistri } \\
\text { busi } \\
\text { Normal }\end{array}$ \\
\hline
\end{tabular}

Berdasarkan tabel.4 dapat disimpulkan bahwa data hasil belajar matematika siswa dengan model pembelajaran Snowball Throwing dan model pembelajaran Talking Stick berdistribusi normal dikarenakan $L_{\text {hitung }}<L_{\text {tabel }}$

\section{Hasil Uji Homogenitas}

Uji homogenitas pada penelitian ini menggunakan Uji-F (Fisher), berdasarkan tabel. 2 dan tabel. 3 diperoleh variansi data hasil belajar menggunakan Snowball Throwing 108,45 dan variansi data hasil belajar menggunakan Talking
Stick 138,75. Adapun untuk memperoleh $F_{\text {hitung }}$ dengan menggunakan rumus

$$
\begin{aligned}
F_{\text {hitung }} & =\frac{\text { Variansi Terbesar }}{\text { Variansi Terkecil }} \\
& =\frac{138,75}{108,45} \\
& =1,279
\end{aligned}
$$

Berdasarkan perhitungan di atas diperoleh harga $F_{\text {hitung }}=1,279$ dan $F_{\text {tabel }}=1,85$ dengan taraf signifikan 0,05. Dikarenakan $F_{\text {hitung }}<F_{\text {tabel }}$ maka dapat disimpulkan bahwa data hasil belajar dengan kedua model pembelajaran tersebut berasal dari populasi homogen.

\section{Hasil Uji Hipotesis}

Dalam menguji hipotesis digunakan kesamaan rata - rata satu pihak dengan menggunakan $u j i-t$ :

$$
t_{\text {hitung }}=\frac{\left|\overline{x_{1}}-\overline{x_{2}}\right|}{S_{g a b} \sqrt{\left(\frac{1}{n_{x_{1}}}+\frac{1}{n_{x_{2}}}\right)}}
$$

Dengan

$S_{g a b}=\sqrt{\frac{\left(n_{x_{1}}-1\right) S_{x_{1}}^{2}+\left(n_{x_{2}}-1\right) S_{x_{2}}^{2}}{n_{x_{1}}+n_{x_{2}}-2}}$

$$
\begin{aligned}
& S_{g a b}=\sqrt{\frac{(30-1) 108,45+(30-1) 138,75}{30+30-2}} \\
& S_{g a b}=\sqrt{\frac{(29) 108,45+(29) 138,75}{58}} \\
& S_{g a b}=11,118
\end{aligned}
$$

Sehingga diperoleh $t_{\text {hitung }}$ sebagai berikut: 
$t_{\text {hitung }}=\frac{\left|\overline{x_{1}}-\overline{x_{2}}\right|}{S_{g a b} \sqrt{\left(\frac{1}{n_{x_{1}}}+\frac{1}{n_{x_{2}}}\right)}}$

$t_{\text {hitung }}=\frac{|80,1-60,83|}{11,118 \sqrt{\left(\frac{1}{30}+\frac{1}{30}\right)}}$

$t_{\text {hitung }}=\frac{19,27}{2,871}$

$t_{\text {hitung }}=6,712$

Berdasarkan tabel nilai kritis distribusi $\mathrm{T}$ dengan $d k=58$ dan $\alpha=0,05$ diperoleh $t_{\text {tabel }}=2,002$. Berdasarkan perhitungan di atas dapat disimpulkan bahwa $t_{\text {hitung }}>t_{\text {tabel }}$ dengan demikian $H_{1}$ diterima dan $H_{0}$ ditolak yang artinya terdapat perbedaan rata - rata hasil belajar matematika siswa menggunakan model pembelajaran Snowball Throwing dengan model Talking Stick pada materi logika matematika dikelas X SMA Asyariah Gintung KabupatenTangerang.

\section{Kesimpulan}

Berdasarkan penelitian yang telah dilaksanakan, diperoleh kesimpulan :

Penggunaan metode yang tepat dalam proses pembelajaran dapat meningkatkan hasil belajar matematika siswa. Pada penelitian ini untuk model pembelajaran Snowball Throwing diperoleh nilai rata rata hasil belajar sebesar 80,1 sedangkan model pembelajaran Talking Stick diperoleh nilai rata - rata hasil belajar 60.83. Berdasarkan perhitungan uji hipotesis denga uji $-\mathrm{t}$ diperoleh $t_{\text {hitung }}=$ 6.712 dan $t_{\text {tabel }}$ pada taraf nyata $\alpha=0,05$ dengan $\mathrm{dk}=58$ sebesar2,002, sehingga dapat disimpulkan $t_{\text {hitung }}>t_{\text {tabel }}$ dengan demikian berarti $H_{0}$ ditolak artinya terdapat perbedaan yang signifikan antara hasil belajar matematika siswa menggunakan model pembelajaran snowball throwing dan model Talking stick.
Daftar Rujukan

Arikunto, Suharsimi. 2006. Prosedur Penelitian Pendidikan Praktis. Jakarta: Rineka Cipta.

2009. Dasar - Dasar Evaluasi Pendidikan. Jakarta :Rineka Cipta.

Hidayat, Syarif. 2012. Profesi Kependidikan, Tangerang :Pustaka Mandiri.

Huda, Miftahul. 2013. Model - Model Pengajaran dan Pembelajaran. Jakarta:Pustaka Sinar Harapan.

Nana Syaodih, Sukmadinata. 2004. Landasan Psikologi Prosedur Pendidikan Bandung: Remaja Rosda Karya.

Nurkancana, Wayan. 2013. Evaluasi Pendidikan. Surabaya: Usaha Offset.

Sugiyono. 2015. Statistika Untuk Penelitian. Bandung: Afabeta. 